\title{
Health Belief Model Analysis of Diarrhea in Students Tulungagung District
}

\author{
Chaecaria Ulfiantika Pramuti ${ }^{1}$, Endang Sri Redjeki ${ }^{2}$, Windi Chusniah Rachmawati ${ }^{3 *}$ \\ ${ }^{1,3}$ Department of Public Health, Faculty of Sport Science, Universitas Negeri Malnag, Malang, East Java, Indonesia \\ ${ }^{2}$ Faculty of Education, Universitas Negeri Malang, Malang, East Java, Indonesia \\ *Corresponding author. Email: windi.rahmawati.fik@um.ac.id
}

\begin{abstract}
The study was conducted to analyze the application of the Health Belief Model theory to the possibility of diarrheal disease prevention behavior in junior high school students. The study was conducted with a cross sectional design with a quantitative approach. The research sample uses a purposive sampling technique with inclusion criteria. The study was analyzed and tested using Somer's D test. The results of this study are that there is a very strong relationship between severity and vulnerability, a strong relationship between obstacles, a moderate relationship between signs of action and the benefits of having a very low relationship. It is recommended to increase preventive and promotive efforts at school by always washing hands with soap and running water.
\end{abstract}

Keywords: health belief model, diarrhea, students

\section{INTRODUCTION}

Diarrhea is a disease where sufferers often defecate with a frequency of three times per day or even more, usually diarrhea is often caused by bacteria such as Salmonella/E.coli [1]. In developing countries such as Indonesia, diarrheal disease still has high morbidity and mortality rates and is still one of the causes of death in the world. Based on data from the Ministry of Health, diarrheal disease in East Java was the highest in Indonesia compared to the previous year with the number of diarrhea sufferers treated by health facilities of 819,729 people [2].

Based on data from the Ministry of Health in 2017, East Java Province was the second highest in Indonesia after West Java Province with the number of sufferers as many as 604,779 people, higher than in 2016 as many as 338,806 people [2]. The risk factors that often occur in diarrheal diseases according to the health department of the control of diarrheal diseases are food poisoning, food allergies, bacteria/viruses, unhealthy drinking water sources, when defecation is not properly latched and also factors of clean and healthy living behavior, such as wash hands after defecation and before eating, dispose of garbage in its place and eat a balanced nutritious diet. The environment determines the degree of public health [3].

According to East Java provincial health data in 2017 [4], the incidence of diarrheal disease in Tulungagung
Regency with the average diarrheal disease being treated is still high at $72 \%$ compared to Malang City on average $49 \%$ and the diarrheal disease rate in Situbondo Regency is 34\%. In 2017 in Tulungagung Regency there was an Extraordinary Event (KLB) of diarrheal disease with 9 sufferers ranging in age from children aged 10-14 years. Based on the health data of Tulungagung Regency in 2017, it describes the highest number of morbidity/incident rates in the working area of the Bandung Health Center, Bandung District, Tulungagung Regency, which is 1,748 patients. However, in 2018 based on health data from Tulungagung Regency, the number of morbidity in diarrheal disease decreased by 43.6\% but in Bandung District, diarrheal disease was still the highest with 1,352 sufferers.

Data from the 2016 EHRA (Environment Health Risk Assessment) Study Report of Tulungagung Regency explains that in the Bandung District, the village most at risk for diarrheal disease is Suruhan Lor village, where flooding often occurs and is a watershed area. Prevention and handling of diarrheal diseases in Tulungagung Regency that have been carried out by the government and the local health center, namely the puskesmas has supervised food vendors in the school environment and ensured its cleanliness, while government officials have done chlorine and provided a number of ORS as first aid. Preventive actions can be taken by individuals through healthy homes and Clean and Healthy Lifestyles (PHBS). 
Data from the Tulungagung District Health Office profile in 2017 noted that $41.6 \%$ of households implemented PHBS, of the 70,315 households monitored, only 20,977 households implemented clean and healthy living behaviors. Recorded in the Bandung Health Center data, the number of households that implement the Clean and Healthy Lifestyle (PHBS) is 1,049 with the number of households being monitored is 3,387 households. Based on urban health data in the working area of the Bandung Health Center, the population is 45,029 , while the target for finding diarrhea is 1,216 people, while diarrhea treated in health facilities is 1,748 people.

Based on these data, it can be concluded that environmental conditions are still one of the problems of diarrheal disease in Tulungagung Regency which is still high with the average diarrheal disease experienced by children caused by unsanitary and healthy food. The government of Tulungagung Regency has taken preventive measures by supervising food vendors in schools to ensure food hygiene, but the poor behavior of the community towards clean and healthy living has become an obstacle for the government in overcoming diarrheal diseases in Tulungagung Regency. Therefore, it is necessary to see and observe the behavior of preventing diarrheal diseases in individuals, especially children aged 10-14 years in the work area of the Bandung Health Center.

Based on Permendikbud No. 14 of 2018 it states that children aged 10-14 years are junior high school (SMP) students. In research conducted by Safirah Sarayati (2016), it is explained that during adolescence 12-18 years old, they have entered a phase or stage of development, namely formal operations, where at that time teenagers use rational thinking and deductive thinking patterns. The concept of the Health Belief Model (HBM) theory is an individual assessment to take preventive measures for diarrheal diseases to behave in a healthy manner. HBM theory is influenced by perceived susceptibility, perceived severity, perceived benefit, perceived barries and cues to action. Perceived susceptibility is an individual's susceptibility factor to a disease. Perceived severity is a factor in the severity or seriousness of the disease experienced. Perceived benefit is a benefit factor for individuals when taking disease prevention measures. Perceived barriers are factors that hinder individuals from taking an action to prevent disease. Cues to action are individual cues to take preventive action in the form of mass media, electronic and non-electronic media.

This study aims to look at individual behavior in preventing diarrhea in the work area of the Bandung Health Center, Tulungagung Regency. In previous studies that have been carried out on the Health Belief Model theory only on the prevention of dengue fever and dental caries, and there has been no research on the prevention of diarrheal diseases using the Health Belief Model theory. Based on this background, the researcher is interested in examining the individual trust factor in preventing diarrheal disease in the Bandung District, Tulungagung Regency using the Health Belief Model theory.

\section{METHOD}

The research used descriptive correlational quantitative approach and the research design was cross sectional. Sampling in this study used a purposive sampling technique with a total sample of 72 people with inclusion criteria, namely students who attended Mtsn 4 Tulungagung district, aged 12-14 years, and had experienced diarrhea for the last 3 months. univariate analysis presented in the form of tables and diagrams. bivariate analysis is presented in tabular form using somer's d test.

\section{RESULTS}

On the perceived severity of diarrheal disease, it can be explained that the disease is not severe to the health of 43 students $(59.72 \%)$. Students who think that diarrhea is not severe if the student has diarrhea for less than 14 days, and there is no pus/blood in the student's feces.

Table 1. Perceived severity of diarrhea

\begin{tabular}{|l|l|c|c|}
\hline Variable & \multicolumn{1}{|c|}{ Indicators } & $\mathrm{n}$ & $\%$ \\
\hline \multirow{2}{*}{$\begin{array}{l}\text { Perceived of } \\
\text { severity }\end{array}$} & Severe & 3 & 4,16 \\
\cline { 2 - 4 } & Quiet severe & 26 & 36,1 \\
\cline { 2 - 4 } & Not severe & 43 & 59,72 \\
\hline
\end{tabular}

On the level of perceived susceptibility to diarrheal diseases, it can be explained that more than half of students have diarrheal diseases that are not caused by transmission from other people, namely 62 students $(86.1 \%)$. Students who feel they are not easily infected assume that students still buy snacks in the school canteen that are not tightly closed.

Table 2. Perceived susceptibility of diarrhea

\begin{tabular}{|l|l|c|c|}
\hline Variable & \multicolumn{1}{|c|}{ Indicators } & $\mathrm{n}$ & $\%$ \\
\hline \multirow{4}{*}{$\begin{array}{l}\text { Perceived of } \\
\text { susceptibility }\end{array}$} & Easy to get infected & 3 & 4,16 \\
\cline { 2 - 4 } & $\begin{array}{l}\text { Queit easy to get } \\
\text { infected }\end{array}$ & 7 & 9,72 \\
\cline { 2 - 4 } & $\begin{array}{l}\text { Difficult to get } \\
\text { infected }\end{array}$ & 62 & 86,1 \\
\hline
\end{tabular}

At the level of health service benefits obtained by students against diarrheal disease, it can be explained that most students feel very useful in getting health services when they feel diarrhea as many as 41 students (56.94\%). Students who think that going to a health care facility or getting medicine at a pharmacy is very useful when they have diarrhea. 
Table 3. Get health service benefit

\begin{tabular}{|l|c|c|c|}
\hline Variable & Indicators & $\mathrm{n}$ & $\%$ \\
\hline \multirow{2}{*}{$\begin{array}{l}\text { Get health } \\
\text { service benefit }\end{array}$} & No & 0 & 0 \\
\cline { 2 - 4 } & Queit & 31 & 43,05 \\
\cline { 2 - 4 } & Very & 41 & 56,94 \\
\hline
\end{tabular}

At the level of obstacles in accessing health services for diarrheal diseases, it can be explained that more than half of students do not become obstacles in obtaining health services, namely 60 students $(83.3 \%)$. This is because students assume that the distance from their homes to health care facilities is quite close and easy to reach.

Table 4. Accessibility to health service

\begin{tabular}{|l|c|c|c|}
\hline Variable & Indicators & $\mathrm{n}$ & $\%$ \\
\hline \multirow{2}{*}{$\begin{array}{l}\text { Accessibility to } \\
\text { health service }\end{array}$} & Difficult & 0 & 0 \\
\cline { 2 - 4 } & Queit & 12 & 16,67 \\
\cline { 2 - 4 } & Easy & 60 & 83,3 \\
\hline
\end{tabular}

At the level of cues for taking action that students get on diarrheal disease, it can be explained that most students often get cues or encouragement in preventing diarrheal disease as many as 44 students (61.1\%). Students who think that they often get cues in taking action against diarrheal disease are because students often get posters/brochures/pictures about prevention of diarrheal diseases by doing clean and healthy living behavior.

Table 5. Cues for taking action

\begin{tabular}{|l|c|c|c|}
\hline Variable & Indicators & $\mathrm{n}$ & $\%$ \\
\hline \multirow{2}{*}{$\begin{array}{l}\text { Cues for taking } \\
\text { action }\end{array}$} & Do nothing & 5 & 6,94 \\
\cline { 2 - 4 } & Seldom & 23 & 31,94 \\
\cline { 2 - 4 } & Always & 44 & 61,1 \\
\hline
\end{tabular}

At the level of possibility of taking action against diarrheal disease, it can be explained that the average student always takes preventive action against diarrheal disease, obtained by 43 students $(59.72 \%)$. Students who think that they always take preventive measures for diarrheal diseases, such as throwing garbage in its place, always eating healthy and clean food, cutting nails once a week, washing food before eating it and checking with health care facilities as a behavior to prevent diarrhea.

Table 6. Get health service benefit

\begin{tabular}{|l|c|c|c|}
\hline Variable & Indicators & $\mathrm{n}$ & $\%$ \\
\hline Possibility of & Do nothing & 3 & 4,16 \\
\cline { 2 - 4 } taking action & Seldom & 26 & 36,1 \\
\cline { 2 - 4 } against diarrhea & Always & 43 & 59,72 \\
\hline
\end{tabular}

The relationship of severity to the possibility of taking action to prevent diarrheal disease shows the results of the analysis that a statistical test value of 0.960 is obtained, meaning that there is a very strong relationship between severity and the possibility of taking action, where if students have a high sense of severity, students will take preventive action. diarrhea is good too.

\section{DISCUSSION}

Attamimy \& Qomaruddin in their research also stated that severity had a strong relationship with dengue prevention efforts and showed a directly proportional relationship [5]. The relationship between the level of vulnerability to the possibility of taking action to prevent diarrhea shows a statistical test result of 0.873 , meaning that it has a very strong relationship between susceptibility to the possibility of taking action, where if students have a low sense of vulnerability or ease of contracting diarrheal disease, students will do the same. good or high diarrheal disease prevention measures. In line with this, Setiari states that there is a fairly strong relationship between the level of susceptibility to dental caries prevention measures [6].

The relationship between the level of benefit and the possible behavior of taking action in preventing diarrheal disease shows an analysis result of 0.087 , which means that it has a very low relationship between the benefits of obtaining health services and the possibility of behavior taking action in preventing diarrheal disease, where if students have a sense of benefit in seeking treatment at the facility. health services is high, then students are less in taking action to seek treatment at health care facilities. In this regard, explains that the level of benefit for dengue prevention efforts shows a weak relationship and has a directly proportional relationship value [5].

The relationship between the level of barriers to the possible behavior of taking action in preventing diarrheal disease in Table 2 obtained a statistical test result of 0.711 , meaning that there is a strong relationship between barriers in accessing health care facilities and the possibility of behavior taking action to prevent diarrheal disease, where if students have difficulty in finding treatment to health care facilities or even their parents forbid them to seek treatment is very high, then the probability of behavior in preventing diarrheal disease that students do will be lower. Another study stated that the level of perceived inhibition did not show a significant relationship to osteoporosis prevention in Iranian women [7].

The relationship between the level of cues for taking action on the possibility of behavior in preventing diarrheal disease shows an analysis result of 0.427 , meaning that it has a moderate relationship between the cues for taking action on the possibility of behavior in preventing diarrheal disease, where if students get encouragement/advice/suggestion/desire that is felt in preventing diarrheal disease is very high, it is likely that students will take action to prevent diarrheal disease. Another study conducted by explains that cues to act are incentives obtained from inside or outside the family, such as doctors, friends, health services, media and educational resources with the results of research on cues 
to action showing a significant increase in the prevention of nutritional osteoporosis [7].

There is a very strong relationship between the perceived severity and the level of perceived vulnerability to the possibility of taking diarrhea prevention measures, while there is a strong relationship between the level of barriers to health services and the likelihood of taking diarrhea prevention measures, at the level of benefit having a very low relationship to the likelihood of take preventive measures against diarrheal disease and the moderate relationship between the level of cues to take action on the possibility of taking preventive measures against diarrhea. So that the severity and susceptibility factors have a very strong relationship to the possibility of taking preventive measures against diarrheal disease.

\section{CONCLUSION}

There were very strong relationship between severity and vulnerability, a strong relationship between obstacles, a moderate relationship between signs of action and the benefits of having a very low relationship. It is recommended to increase preventive and promotive efforts at school by always washing hands with soap and running water

\section{AUTHORS' CONTRIBUTIONS}

CUP collects data, analyzes and compiles articles. ESR as supervising lecturer and WCR as correspondent author who compiles articles according to context and grammar.

\section{ACKNOWLEDGMENTS}

The authors thank the Tulungagung District Health Office for giving the author permission to collect data and collect data for the target. Thanks also to all the research sample students who have worked well together so that the research objectives were able to be fulfilled.

\section{REFERENCES}

[1]. WHO. Diarrhoeal Disease [Internet]. 2017. Available from: https://www.who.int/en/newsroom/fact-sheets/detail/diarrhoeal-disease.

[2]. Kementerian Kesehatan R. Data dan Informasi Profil Kesehatan Republik Indonesia Tahun 2017. Jakarta: Kementerian Kesehatan Republik Indonesia.; 2018.

[3]. Notoadmodjo S. Promosi Kesehatan Dan Ilmu Perilaku. Jakarta: PT Rineka Cipta.; 2012.

[4]. Dinas Kesehatan. Profil Kesehatan Provinsi Jawa Timur 2017. Jawa Timur: Dinkes JATIM.; 2018.

[5]. Attamimy, H., \& Qomaruddin M. Aplikasi Health Belief Model Pada Perilaku Pencegahan Demam Berdarah Dengue. J Promkes, 245 - 255. 2017;

[6]. Setiari LS S. Tindakan Pencegahan Karies Gigi Pada Siswa Sekolah Dasar Berdasarkan Teori Health Belief Model. J Promkes, 59 - 70. 2017;

[7]. Jeihooni, A. K., Hidarnia, A., Kaveh, M. H., Hajizadeh, E., \& Askari A. Application of the health belief model and social cognitive theory for osteoporosis preventive nutritional behaviors in a sample of Iranian women. 2016. 